\title{
A Tentative Classification of Recessively Inherited Ataxias
}

\author{
ANDRE BARBEAU
}

ABSTRACT: We present a working classification of recessively inherited ataxic syndromes based on the use of simple tools available to every clinician: a good history (particularly pinpointing the age of onset) and a good neurological examination (simplified to the verification of the presence of ataxia, deep tendon reflexes in the knee, optic nerve, retinal and/or 8 th nerve signs). In the three groups of disorders (non progressive, intermittent or progressive) patients can be hyper/normo reflexic, or they can be hypo/areflexic. Six principal types of progressive ataxic disorders are further delineated by the age of onset. Sub-types depend on the presence or absence of eye and ear signs, whereas eponymic or regional denominations are used only for simplicity while awaiting exact delineation of the biochemical defects.

RÉSUMÉ: Nous présentons une classification de travail des syndromes ataxiques héréditaires à transmission récessive qui n'emploi que les outils disponibles $\dot{a}$ tout clinicien: une bonne anamnèse (délimitant particulièrement l'âge de début) et un bon examen neurologique (nous avons simplifié celui-ci à la vérification de la présence d'une ataxie, de réflexes ostéo-tendineux aux genous et de signes oculaires, rétiniens ou du 8 e nerf). Dans les trois groupes de désordres identifiés (non progressifs, intermittents ou progressifs) les patients peuvent être hyper/normo-réflexiques ou hypo/aréflexiques. Six principaux types de maladies ataxiques progressives ont pu être identifiés grâce à ce critère et à l'âge de début. Les sous-types sont caractérisés par la présence ou l'absence de signes oculaires ou auditifs, tandis que les dénominations éponymiques ou régionales sont employées temporairement en attendant la découverte des marqueurs biochimiques.

From the Department of Neurobiology, Clinical Research Institute of Montreal.

Reprint request for the complete supplement (Phase Three, part Two) to: Prof. Andre Barbeau, Clinical Research Institute of Montreal, 110 Pine Avenue West, Montreal, Quebec, Canada, H2W 1 R 7.

\section{INTRODUCTION}

One of the hardest tasks facing the student of ataxic disorders is the problem of where to classify individual cases, seemingly always presenting with a slightly different picture to the previous one. This problem has haunted all neurologists and geneticists since the first attempts of Bell and Carmichael (1939) and has resulted in many proposals over the years, none of which have proved to be entirely satisfactory (Sjögren, 1943; Greenfield, 1954; Schwarz, 1952, 1956; Königsmark and Weiner, 1970). Over the last 6 years we have been able to examine clinically more than 300 patients with inherited ataxic disorders, and have constantly faced this problem. Tentative classifications were elaborated, but soon dropped when a new group defied characterization. The difficulties were worse in ataxic families presenting with autosomal recessive inheritance. We therefore decided to study this problem and to try to elaborate a classification of recessively inherited ataxic disorders which could be used by any physician in his office asking only very simple questions and carrying out only a standard neurological examination. We present this classification only for discussion and suggestions, and not as a definitive work.

\section{METHODOLOGY}

The first questions to be asked are: Is this case hereditary or non hereditary? If hereditary, is the pattern sex-linked recessive, autosomal dominant or autosomal recessive? For the purposes of the present paper we will consider only the latter presentation, ie autosomal recessive inheritance. As seen in Table 1, three possibilities can then be faced: the ataxic disorder is non progressive, intermittent or pro- gressive, facts which can easily be elicited from the history. In each category the next question is: what is the state of deep tendon reflexes? To standardize things, and because it is the most reproducible and best known reflex, we have chosen the knee jerk as our basic criterion. The knee jerk can be hyper or normo-active or it can be clearly hypoactive (or even inactive). This simple test already permits a delineation of most clinical syndromes encountered.

The next step in our classification process is to enquire from the patient, or preferably from the family, as to the actual age of onset of the very first abnormal symptom. Again three possibilities exist: early onset (from 0 to 2 years); onset in childhood or adolescence (from age 2 to 20 ) and adult onset (after age 21 ). These broad categories have been chosen to conform as much as possible with the classically defined lines between infants, children and adults. As seen in Table 1 , this process defines 6 types of progressive recessively inherited ataxias, all easily classifiable by any clinician.

Unfortunately, patients do not present with pure clinical tableaux. The principal symptom guiding our selection was ataxia, ie incoordination of gait and limbs. The presence of some mental retardation is so common in many of the ataxic disorders, particularly at both ends of the age spectrum, that it cannot be used as a discriminating factor. However other symptoms can. As noted by Franceschetti et al (1963), optic atrophy, retinal and eight nerve changes are frequently seen in the ataxias. This usually signals the presence of a more widespread disorder, or of a fairly advanced stage of the disease. It can equally be used to further discriminate between many of the entities previously delineated. We therefore decided to add 


\section{TABLE II}

Classification of Recessively Inherited Ataxias List of Identified Syndromes

\section{A. Non Progressive Recessively Inherited Ataxias}

\section{a) Hyper-reflexic}

1. congenital ataxic diplegia (Gustavson) ${ }^{20}$

2. congenital dysequilibrium syndrome (Sanner) ${ }^{41}$

\section{b) Hypo-reflexic}

1. congenital, non-progressive, cerebellar ataxia (BattenLamy) ${ }^{529}$, (also called recessive infantile spastic diplegia).

\section{B. Intermittent Ataxias}

a) Hereditary hyperammonemias associated with ataxia 40
1. congenital hyperammonemia type II
2. citrullinemia
3. argeninosuccinic aciduria
4. hyperornithinemia

b) Hyperalaninemic and hyperpyruvate states $^{9}$

1. intermittent cerebellar ataxia

2. necrotizing encephalopathy (Leigh's disease)

c) Hartnup disease ${ }^{3}$

d) Branched-chain Ketonuria ${ }^{14}$

\section{Progressive Recessively Inherited Ataxias}

a) Hyper or Normo-Reflexic

1. Early onset (Type I)

Type 1a 1. Ataxia-Telangiectasia ${ }^{31}$ (Louis-Bar Syndrome)

2. Amyotrophic familial spastic paraplegia ${ }^{37}$

3. Troyer Syndrome ${ }^{13}$

4. Charlevoix-Saguenay Syndrome ${ }^{10}$

5. Lesch-Nyhan Syndrome ${ }^{30}$

Type lb 1. Behr's Disease ${ }^{24}$

2. Sjögren-Larsson Syndrome ${ }^{46}$

3. Congenital ataxia and aniridia ${ }^{18}$

(Gillespie Syndrome)

4. Marinesco-Sjögren Sydrome ${ }^{33} 45$

5. Progressive ophthalmoplegia and ataxia ${ }^{12}$

6. Ataxia, deafness and mental retardation (ADR syndrome) ${ }^{7}$

2. Childhood and adolescence onset (Type II)

Type IIa 1. Hereditary recessive spastic ataxia ${ }^{6}$ (R-SCD or recessive spino-cerebellar degeneration)

2. Early onset cerebellar ataxia with retained tendon reflexes ${ }^{22}$
Type IIb 1. R-SCD with blindness and deafness (Hallgren's syndrome) ${ }^{21}$

2. R-SCD and slow eye movements ${ }^{16}$

3. The Beauce R-SCD syndrome ${ }^{2}$

4. Ataxia, deafness and oligophrenia syndrome (Jeune) $^{26}$

5. Familial ataxia with peroneal muscular atrophy and optic atrophy

6. Nephronophthisis with progressive ataxia and retinal pigmentation ${ }^{35}$

\section{Adult and late onset (Type III)}

Type IIIa 1. Fickler-Winkler, recessive cerebellar atrophy of late onset ${ }^{28}$

Type IIIb1. Spastic paraplegia, oligophrenia, amyotrophy and retinal degeneration (Kjellin Syndrome) $)^{27}$

2. Cerebellar ataxia and hypogonadism (Richards and Rundle Syndrome) ${ }^{38}$

b) Hypo-Reflexic

(1) Early onset (Type IV)

Type IVa 1 . Hereditary sensory neuropathy with ataxia $^{23} 25$

Type IVb 1. HSN-Type 3, with dysautonomia (RileyDay) $)^{39}$

(2) Childhood and adolescent onset (Type V)

Type Va 1. Friedreich's ataxia ${ }^{17}$

2. Friedreich's ataxia (rapid progression)

(Rimouski sub-type) ${ }^{11}$

3. Friedreich's ataxia - very slow progression (Acadian sub-type $)^{1}$

4. Friedreich's ataxia with neurogenic muscular atrophy ${ }^{48}$

5. Recessive HMSN (so-called recessive Roussy-Levy Syndrome) ${ }^{47}$

Type Vb 1. Bassen-Kornzweig disease ${ }^{4}$

2. Refsum's heredopathia atactica polyneuritiformis ${ }^{36}$

3. Polyneuropathy, oligophrenia, premature menopause, and acromicria (Lundgerg's syndrome) $)^{32}$

(3) Adult and late onset (Type VI)

Type VIa 1. Gamma-glutamylcystëine Synthetase (GGCS) deficiency ${ }^{38}$ 
TABLE 1:

A Proposed Classification of Recessively Inherited Ataxias

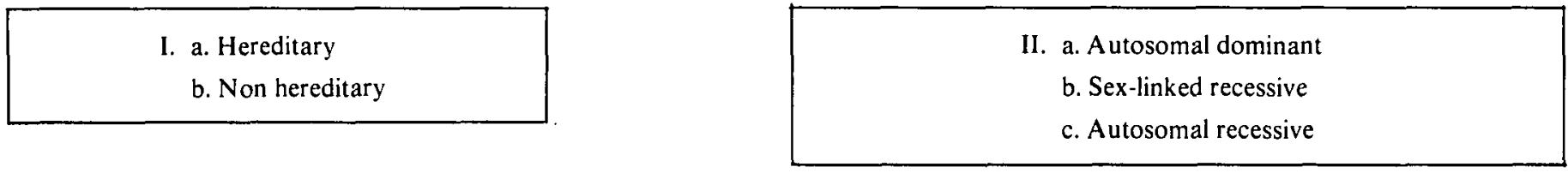

III. Recessively inherited ataxias

A. Non progressive ataxias

B. Intermittent ataxias

C. Progressive Ataxias a) hyper-reflexic

b) hypo-reflexic

Early onset (Type I)

a) Hyper and normo-reflexic

Childhood \& Adolescence (Type II)

Adult onset (Type III)

Early onset (Type IV)

Childhood \& Adolescence (Type V)

Adult onset (Type VI) sub-types to the 6 types obtained through examination of deep tendon reflexes and age of onset. The two subtypes are (a) where ataxia ( \pm mental retardation) is the principal symptom and is not accompanied by eye (optic nerve or retinal) or ear (8th nerve) symptoms; (b) where ataxia ( \pm mental retardation) is accompanied by eye or ear signs.

To further characterize the individual entities, names must sometimes be used. Until a definitive biochemical marker can be given to each disease, the use of eponymic identification must be tolerated because it is within our customs. Moreover, since many disorders tend to occur in high concentration in defined geographic isolates, we have found it convenient to use regional identification (ie Charlevoix-Saguenay syndrome; Acadian type of ataxia etc.) It should be emphasized, however, that these designations are only temporary, destined to be replaced by proper identification of the biochemical or enzymatic defect. For example Refsum's disease should be called "Phytanic acid storage disease".

Using these criteria, we searched the literature and examined our few hundred patients to elaborate the following classification, which we present as a working document without any further justification. We solicit comments and discussion from the eventual readers . . . and users.

\section{RESULTS}

The classification is presented in detail in Table 2.

\section{ACKNOWLEDGEMENTS}

The studies on ataxia in the author's laboratory are supported by grants from: l'Association Canadienne de l'Ataxie de Friedreich; the O. Mallette Foundation of the Hotel-Dieu Hospital; the Fondation Yvon Deschamps and the Ministry of Health and Welfare (Ottawa). My thanks are extended to Mrs. Hélène L. Crête for typing the manuscript and to the various collaborators who have examined patients with me during our attempts at classification: Drs. M. Roy, L. Boyer, F. Délisle, R. Bouchard, J.P. Bouchard and E. Pourcher.

\section{REFERENCES}

1. BARBEAU, A. (1980) Distribution of Ataxia in Quebec. in Spinocerebellar Degenerations (Ed. I. Sobue). Univ. Tokyo Press, pp. 121-141.

2. BARBEAU, A.; BOUCHARD, J.P.; BOUCHARD, R.; POURCHER, E. and ANDERMANN, F. (1982) A large family with a multitude of recessively inherited ataxia phenotypes (The Beauce Syndrome). In preparation.

3. BARON, D.N.; DENT, C.E.; HARRIS, H.; HART, E.W. and JEPSON, J.B. (1956) Hereditary pellagra-like skin rash with temporary cerebellar ataxia, constant renal amino aciduria, and other bizarre biochemical features. Lancet 2: 421-428.

4. BASSEN, F.A. and KORNZWEIG, A.L. (1950) Malformation of the erythrocytes in a case of atypical retinitis pigmentosa. Blood 5: $381-386$.

5. BATTEN, F.E. (1905) Ataxia in childhood. Brain 28: 484-505.

6. BELL, J.M. and CARMICHAEL, E.A. (1939) On hereditary ataxia and spastic paraplegia. Treas. Hum. Inherit. 4: 141-281. 
7. BERMAN, W.; HASLAM, R.H.A.; KONIGSMARK, B.W.; CAPUTE, A.J. and MIGEON, C.J. (1973) A new familial syndrome with ataxia, hearing loss, and mental retardation. Arch. Neurol. 29: 258-261.

8. BERNABO'BREA, G.; RATHSCHULER, R. and RASORE-QUARTINO, A. (1966) Familial ataxia with peroneal muscular atrophy and optic atrophy. Riv. Oto-NeuroOftal. 41: 273-290.

9. BLASS, J.P.; AVIGAN, J. and UHLEN DORF, B.W. (1970) A defect in pyruvate decarboxylase in a child with intermittent movement disorder. J. Clin. Invest. 49: 423432

10. BOUCHARD, J.P.; BARBEAU, A.; BOUCHARD, R. and BOUCHARD, R.W. (1978) Autosomal recessive spastic ataxia of Charlevoix-Saguenay. Can. J. Neurol. Sci. 5: 61-69.

11. BOUCHARD, J.P., BARBEAU, A.; BOUCHARD, R.; PAQUET, $M$. and BOUCHARD, R.W. (1979). A cluster of Friedreich's ataxia in Rimouski, Quebec. Can. J. Neurol. Sci. 6: 205-208.

12. CROFT, P.B.; CUTTING, J.C.; JEWES BURY, E.C.O.; BLACKWOOD, W. and MAIR, W.G.P. (1977) Ocular myopathy (progressive external ophtholmoplegia) with neuropathic complications. Acta Neurol. Scandina. 55: 169-197.

13. CROSS, H.E. and McKUSICK, V.A. (1967) The Troyer syndrome: a recessive form of spastic paraplegia with distal muscle wasting. Arch. Neurol. 16: 473-485.

14. ELSAS, L.J.; PRIEST, J.H.; WHEELER, F.B.; DANNER, D.J. and PASK, B.A. (1974) Maple Syrup Urine Disease: coenzyme function and prenatal monitoring. Metabolism 23: 569-579.

15. FRANCESCHETTI, A.; FRANCOIS, J.; BABEL, J.; DE ROUCK, A.; DIETERLE, P.; FORNI, S.; KLEIN, D.; RICCI, A. and VERRIEST, G. (1963) Les hérédo-dégénérescences choroido-rétiniennes (Dégénérescences tapéto-rétiniennes), Masson, $P$ aris.

16. GARCIN, R. and MAN, H.X. (1958) Sur la lenteur particulière des mouvements conjugués des yeux observée fréquemment dans les dégénérations cérébelleuses et spinocérébelleuses: la viscosité des mouvements volontaires. Revue Neurol. (Paris) 98: 672689.

17. GEOFFROY, G.; BARBEAU, A.; BRETON, G.; LEMIEUX, B.; AUBE, M.; LEGER, C. and BOUCHARD, J.P. (1976) Clinical description and roentgenologic evaluation of patients with Friedreich's ataxia. Can. J. Neurol. Sci. 3: 279-286.

18. GILLESPIE, F.D. (1965) Aniridia, cerebellar ataxia and oligophrenia in siblings. Arch. Ophthal. 73: 338-341.

19. GREENFIELD, J.G. (1954) The spinocerebellar degenerations. Springfield, Illinois.
20. GUSTAVSON, K.H.; HAGBERG, B. and SANNER, G. (1969) Identical syndromes of cerebral palsy in the same family. Acta Paediat. Scan. 58: 330-340.

21. HALLGREN, B. (1959) Retinitis pigmentosa combined with congenital deafness, vestibulo-cerebellar ataxia and mental abnormality in a proportion of cases. Acta Psychiat. Scand. Suppl. 34: 138.

22. HARDING, A.E. (1981) Early onset cerebellar ataxia with retained tendon reflexes: a clinical and genetic study of a disorder distinct from Friedreich's ataxia. J. Neurol. Neurosurg. Psychiat. 44: 503-508.

23. HELLER, I. and ROBB, P. (1955) Hereditary sensory neuropathy. Neurology (Minn.) 5: 15-29.

24. HOROUPIAN, D.; ZUCHER, S. and MO SHE, O.K. (1979) Behr syndrome: a clinicopathologic report. Neurology 29: 323.

25. HOULD, F. and VERRET, S. (1967) Neuropathie radiculaire héréditaire avec pertes de sensibilité: étude d'une famille canadienne-française. Laval Méd. 38: 454459.

26. JEUNE, M.; TOMMASI, M.; FREYCON, F. and NIVELON, J. (1963) Syndrome familial associant ataxie, surdité et oligophrénie. Sclérose myocardique d'évolution fatale chez l'un des enfants. Pédiatrie 18: 984-987.

27. KJELLIN, K.G. (1959) Familial spastic paraplegia with amyotrophy, oligophrenia and central retinal degeneration. Arch. Neurol. (Chic.) 1: 133-140.

28. KONIGSMARK, B.W. and WEINER, L.P. (1970) The olivopontocerebellar atrophies: a review. Medicine 49: 227-233.

29. LAMY, M.; GRASSET, A.; JAMMET, M.L. and VIARD, F.R. (1963) L'ataxie cérébelleuse héréditaire de l'enfance. Arch. franc. Pédiat. 20: 5-15.

30. LESCH, M. and NYHAN, W.L. (1964) A familial disorder of uric acid metabolism and central nervous system function. Am. J. Med. 36: 561-570.

31. LOUIS-BAR, D. (1941) Sur un syndrome progressif comprenant des télangiectasies capillaires cutanées et conjonctivales symétriques, à disposition naevoide et de troubles cérébelleux. Confin. neurol. (Basel) 4: 32-42.

32. LUNDBERG, P.O. (1971) Hereditary polyneuropathy, oligophrenia, premature menopause and acromicria. Eur. Neurol. 5: 84-98.

33. MARINESCO, G.; DRAGONESCO, S. and YASILIN, D. (1931) Nouvelle maladie familiale caractérisée par une cataracte congénitale et un arrêt du développement somato-neuro-psychique. Encéphale 26: 97 109.
34. MATHEWS, W.G. and RUNDLE, A.T. (1964) Familial cerebellar ataxia and hypogonadism. Brain 87: 463-468.

35. POPOVIC-ROLOVIC, M.; CALICPERISIC, N. and BUNJEVACKI, G. (1976) Juvenile nephronophthisis associated with retinal pigmentary dystrophy, cerebellar ataxia, and skeletal abnormalities. Arch. Dis. Child. 51: 801-805.

36. REFSUM, S. (1946) Heredopathia atactica polyneuritiformis: a familial syndrome not hitherto describes. A contribution to the clinical study of the hereditary diseases of the nervous system. Acta. psychiat. Scand. Suppl. 38: 1-303.

37. REFSUM, S. and SKILLICORN, S.A. (1954) Amyotrophic familial spastic paraplegia. Neurology (Minn). 4: 40-47.

38. RICHARDS, F.; COOPER, M.R. and PEARCE, L.A. (1974) Familial spinocerebellar degeneration, hemolytic anemia, and glutathione deficiency. Arch. Int. Med. 134: 534.

39. RILEY, C.M.; DAY, R.L.; GREELEY, D.M.; and LANGFORD, W.S. (1949) Central autonomic dysfunction with defective lacrimation. I. Report of five cases. Pediatrics 3:468.

40. SALAM, M. (1975) Metabolic ataxias. in Handbook of Clinical Neurology (Ed. Vinken, P.J. and Bruyn, G.W.) Vol. 2, pp. 573-585.

41. SANNER, G. (1973) The dysequilibrium syndrome. A genetic study. Neuropédiatrie 4: 403-413.

42. SCHWARZ, G.A. (1952) Hereditary (familial) spastic paraplegia. Arch. Neurol. Psychiat. (Chic.) 68: 655-682.

43. SCHWARZ, G.A. (1956) Hereditary (familial) spastic paraplegia. Further clinical and pathologic observations. Arch. Neurol. Psychiat. (Chic.) 75: 144-162.

44. SJÖGREN, T. (1943) Klinische and erbbiologische untersuchungen uber die heredoataxien. Acta Psychiat. (Kbh), Suppl. 27: 1197.

45. SJÖGREN, T. (1950) Hereditary congenital spinocerebellar ataxia accompanied by congenital cataract and oligophrenia. Convin. Neurol. (B asel) 10: 293-308.

46. SJÖGREN, T. and LARSSON, T. (1957) Oligophrenia in combination with congenital ichthyosis and spastic disorders. Acta Psychiat. Neurol. Scand. 32: suppl. 113: 1112.

47. SKRE, H. (1974) Genetic and clinical aspects of Charcot-Marie-Tooth's disease. Clin. Genet. (Copenhagen) 6: 98-118.

48. VAN BOGAERT, L. and MOREAU, $\mathrm{H}$ (1939) Combinaison de l'amyotrophie de Charcot-Marie-Tooth et de la maladie de Friedreich chez plusieurs membres d'une mème famille. Encéphale 34: 312-320. 